\title{
Commentary: Aortic aneurysms are not created equal
}

\author{
Vikram Sood, MD, and Ming-Sing Si, MD
}

\author{
From the Section of Pediatric Cardiovascular Surgery, Department of Cardiac Surgery, University of Michigan, \\ Ann Arbor, Mich. \\ Disclosures: Authors have nothing to disclose with regard to commercial support. \\ Received for publication Sept 13, 2019; revisions received Sept 13, 2019; accepted for publication Sept 13, 2019; \\ available ahead of print Sept 20, 2019. \\ Address for reprints: Ming-Sing Si, MD, 11-735 C.S. Mott Children's Hospital, SPC 4204, 1540 E Hospital Dr, \\ Ann Arbor, MI, 48109-4204 (E-mail: mingsing@umich.edu). \\ J Thorac Cardiovasc Surg 2020;160:e261-2 \\ $0022-5223 / \$ 36.00$ \\ Copyright (c) 2019 by The American Association for Thoracic Surgery \\ https://doi.org/10.1016/j.jtcvs.2019.09.013
}

Potentially lethal complications, such as rupture and dissection, are more common as aortic aneurysm size increases. ${ }^{1}$ It is therefore universally accepted that replacement of the aneurysmal aorta is a preventive treatment for these complications. Determining the size threshold at which to intervene is a more complicated issue; furthermore, patients with genetic aortopathies, such as Marfan syndrome are recommended to undergo earlier intervention because dissection can occur at smaller aortic diameters. ${ }^{2,3}$ The lack of a more personalized approach to aortic aneurysmal disease commonly leads to everyday clinical dilemmas as to when intervention should be recommended, especially for patients with congenital heart diseases (eg, tetralogy of Fallot and bicuspid aortic valve [BAV]) that may be associated with inherently large aortic roots and aortas. ${ }^{4,5}$ Clearly, a more data-driven approach to the dilated aorta is needed to guide clinical decision making on an individual patient basis.

In this month's edition of the Journal, Chim and colleagues ${ }^{6}$ present a novel micromechanical and microstructural approach to differentiate BAV aortopathy from idiopathic aneurysmal aortopathy. The data are limited by sample size $(\mathrm{N}=39)$ and the lack of an optimal control group; nevertheless, this study indicates that BAV aortopathy is associated with reduced vessel wall compliance relative to idiopathic aneurysmal aortopathy and nonaneurysmal aortas. As such, Chim and colleagues ${ }^{6}$ postulate that BAV aortopathy may require specific guidelines for intervention, because its microstructure is inherently different from that of idiopathic aneurysmal aortopathy. Though there are limitations to their data, their analysis with nanoindentation demonstrates that aortopathies do possess specific biomechanical signatures.

The goal of all studies that determine the biomechanical properties and important biomarkers of aortopathy is to predict which patients would benefit from earlier intervention-and, conversely, which patients would benefit from delayed intervention and continued surveillance. The next step in the clinical translation of this

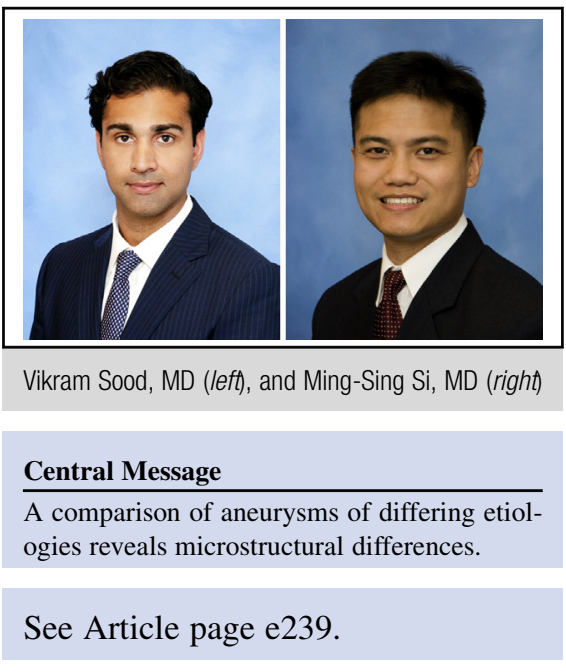

study by Chim and colleagues ${ }^{6}$ is to determine how these microstructural changes and changes in stiffness actually influence the failure mechanics of aortic aneurysmal tissue. Specifically, studies would need to measure directly either the aneurysmal tissue toughness ${ }^{7}$ or the amount of energy required to cause irreversible failure. This is not clinically practical, however, because it requires direct testing of resected aortic tissue. Alternatively, understanding how specific biomarkers and non-failure-related biomechanical parameters relate to toughness and other failure-related biomechanical properties would have the most clinical impact.

Although treatment and fundamental understanding of aortopathies have seen significant progress during the past few decades, the key issue of predicting aneurysmal complications on an individual patient basis remains unanswered. Continued research and advances in imaging, structural mechanics and characterization, biomarkers, and genetics are therefore needed to address this unmet medical need.

\section{References}

1. Davies RR, Goldstein LJ, Coady MA, Tittle SL, Rizzo JA, Kopf GS, et al. Yearly rupture or dissection rates for thoracic aortic aneurysms: simple prediction based on size. Ann Thorac Surg. 2002;73:17-27; discussion 27-8.

2. Pape LA, Tsai TT, Isselbacher EM, Oh JK, O'Gara PT, Evangelista A, et al; International Registry of Acute Aortic Dissection (IRAD) Investigators. Aortic diameter $\geq 5.5 \mathrm{~cm}$ is not a good predictor of type A aortic dissection: observations from the international registry of acute aortic dissection (IRAD). Circulation. 2007;116: 1120-7.

3. Gott VL, Greene PS, Alejo DE, Cameron DE, Naftel DC, Miller DC, et al. Replacement of the aortic root in patients with Marfan's syndrome. $N$ Engl J Med. 1999;340:1307-13. 
4. Schäfer M, Browne LP, Morgan GJ, Barker AJ, Fonseca B, Ivy DD, et al. Reduced proximal aortic compliance and elevated wall shear stress after early repair of tetralogy of Fallot. J Thorac Cardiovasc Surg. 2018;156:2239-49.

5. Opotowsky AR, Perlstein T, Landzberg MJ, Colan SD, O'Gara PT, Body SC, et al A shifting approach to management of the thoracic aorta in bicuspid aortic valve. $J$ Thorac Cardiovasc Surg. 2013:146:339-46.
6. Chim YH, Davies HA, Mason D, Nawaytou O, Field M, Madine J, et al Bicuspid valve aortopathy is associated with distinct patterns of matrix degradation. J Thorac Cardiovasc Surg. 2020;160:e239-57.

7. Hearn EJ. Chapter 1: simple stress and strain. In: Hearn EJ, ed Mechanics of Materials 1. 3rd ed. Woburn, MA: ButterworthHeinemann; 1997:1-26. 